\title{
Highly efficient gold(I)-catalyzed Overman rearrangement in water
}

Dong Xing and Dan Yang*

\section{Letter}

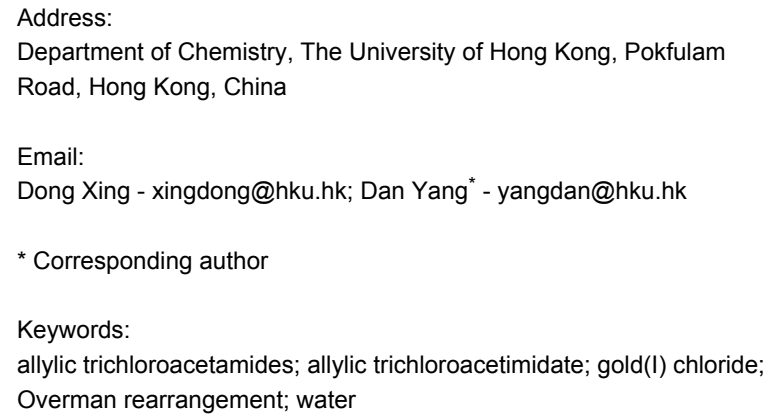

Beilstein J. Org. Chem. 2011, 7, 781-785.

doi:10.3762/bjoc.7.88

Received: 09 April 2011

Accepted: 24 May 2011

Published: 08 June 2011

This article is part of the Thematic Series "Gold catalysis for organic synthesis".

Guest Editor: F. D. Toste

(c) 2011 Xing and Yang; licensee Beilstein-Institut.

License and terms: see end of document.

\begin{abstract}
A highly efficient gold(I)-catalyzed Overman rearrangement of allylic trichloroacetimidates to allylic trichloroacetamides in water is reported. With this environmentally benign and scalable protocol, a series of C3-alkyl substituted allylic trichloroacetamides were synthesized in good to high yields.
\end{abstract}

\section{Introduction}

The aza-Claisen rearrangement of allylic trichloroacetimidates to allylic trichloroacetamides (Overman rearrangement) is a powerful and attractive strategy for the synthesis of allylic amines from readily available allylic alcohols $[1,2]$. This transformation can be conducted thermally at high temperatures or by transition metal catalysis under very mild conditions [3-7]. Asymmetric induction has been achieved with certain types of transition metal catalysts (e.g., palladium complexes) in combination with chiral ancillary ligands [8-13]. However, although a large number of late transition metal catalysts have been used for different types of [3,3]-sigmatropic rearrangements [14,15], only $\mathrm{Pd}(\mathrm{II})$ and $\mathrm{Hg}(\mathrm{II})$ salts have found wide application in
Overman rearrangements. In recent years, gold catalysts have been successfully applied to a series of [3,3]-sigmatropic rearrangements, such as the rearrangement of propargylic esters to allenyl esters [16-21], allenyl carbinol esters to 1,3-butadien2-ol esters [22] and the isomerization of allylic acetates [23,24]. However, when they were used as catalysts for the Overman rearrangement, the substrate scope was limited and only poor to moderate yields were achieved [25-28]. Very recently, our group developed an efficient gold(I)-catalyzed decarboxylative aza-Claisen rearrangement of allylic $N$-tosylcarbamates for the synthesis of $N$-tosyl allylic amines [29]. This reaction was performed in water and therefore represented an environ- 
mentally benign protocol [30-34]. We decided to apply this extremely mild catalytic system to the Overman rearrangement of allylic trichloroacetimidates.

\section{Results and Discussion}

Trichloroacetimidate 1a was prepared by the DBU-catalyzed addition of trans-2-penten-1-ol to trichloroacetonitrile [10,35]. With this substrate, the catalytic activities of different gold(I) complexes in $\mathrm{H}_{2} \mathrm{O}$ were examined. When 1a was subjected to the optimal catalytic conditions previously reported by our group ( $5 \mathrm{~mol} \% \mathrm{AuCl} / \mathrm{AgOTf}$ at $75^{\circ} \mathrm{C}$ ) [29], the desired allylic trichloroacetamide $2 \mathrm{a}$ was obtained in $91 \%$ yield in a reaction time of $1 \mathrm{~h}$ (Table 1, entry 1). Gold(I) complexes with phosphine ligands, $\mathrm{Au}\left(\mathrm{PPh}_{3}\right) \mathrm{Cl}$ or $\mathrm{Au}\left[\mathrm{P}(t-\mathrm{Bu})_{2}(o-\mathrm{Ph}) \mathrm{Ph}\right] \mathrm{Cl}$, in place of $\mathrm{AuCl}$ gave none of the desired product (Table 1, entries 2 and 3). Further screening revealed that $\mathrm{AuCl}$ alone could catalyze this reaction with high efficiency to give $\mathbf{2 a}$ in $92 \%$ yield in $2 \mathrm{~h}$ (Table 1, entry 4). On the other hand, with only AgOTf as the catalyst, the formation of 2a was not observed and substrate 1a decomposed completely (Table 1, entry 5). In the absence of $\mathrm{AuCl}$, substrate 1a remained unreacted, even when the temperature was increased to $100{ }^{\circ} \mathrm{C}$ for $3 \mathrm{~h}$ (Table 1 , entry 6), indicating that the gold(I) catalyst is indispensible for this transformation. This gold(I)-catalyzed reaction could be performed at room temperature, albeit with a prolonged reaction time (Table 1, entry 7). When the temperature was raised to $55{ }^{\circ} \mathrm{C}$ the reaction was complete within $2 \mathrm{~h}$ and in excellent yield (94\%; Table 1, entry 8 ).

With the optimized reaction conditions in hand, the substrate scope of this gold(I)-catalyzed Overman rearrangement was
Table 1: Optimization of reaction conditions. ${ }^{\text {a }}$

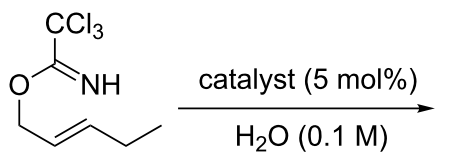<smiles>C=CC(CC)NC(=O)C(Cl)(Cl)Cl</smiles>

$1 a$

2a

\begin{tabular}{clccc}
\hline Entry & Catalyst $(\mathrm{mol} \%)$ & $\begin{array}{c}\text { Temp } \\
\left({ }^{\circ} \mathrm{C}\right)\end{array}$ & $\begin{array}{c}\text { Time } \\
(\mathrm{h})\end{array}$ & $\begin{array}{c}\text { Yield } \\
(\%)^{\mathrm{b}}\end{array}$ \\
\hline 1 & AuCl/AgOTf & 75 & 2 & 91 \\
2 & AuPPh $_{3} \mathrm{Cl} / \mathrm{AgOTf}$ & 75 & 12 & $<5$ \\
3 & Au[P(t-Bu) $\left.)_{2}(o-\mathrm{Ph}) \mathrm{Ph}\right] \mathrm{Cl}$ & 75 & 12 & $<5$ \\
4 & IAgOTf & 75 & 2 & 92 \\
5 & $\mathrm{AuCl}$ & 75 & 12 & $<5$ \\
6 & - & 100 & 3 & $<5$ \\
7 & $\mathrm{AuCl}$ & $\mathrm{rt}$ & 12 & 90 \\
8 & $\mathrm{AuCl}$ & 55 & 2 & 94 \\
\hline
\end{tabular}

aReaction conditions: $0.3 \mathrm{mmol}$ of substrate, $5 \mathrm{~mol} \%$ of the catalyst, $3 \mathrm{~mL} \mathrm{H}_{2} \mathrm{O}$; ${ }^{b}$ yield determined by ${ }^{1} \mathrm{H}$ NMR with nitrobenzene as internal standard.

surveyed. Different alkyl substituents at the $\mathrm{C} 1$ position of allylic trichloroacetimidates, including methyl (1b), ethyl (1a), $n$-propyl (1c) and phenethyl (1d) groups, underwent the desired transformation smoothly to afford the corresponding C3-alkyl substituted allylic trichloroacetamides in high yields (Table 2, entries 1-4). The C1-diethylmethyl substituted substrate (1e) also underwent the desired rearrangement, affording the desired

Table 2: Gold(I)-catalyzed Overman rearrangement in $\mathrm{H}_{2} \mathrm{O}$.

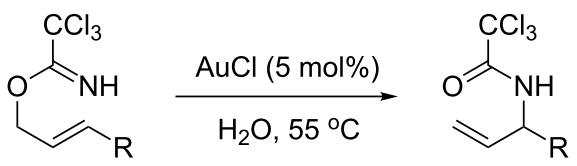

1

2

Entry Substrate


Table 2: Gold(I)-catalyzed Overman rearrangement in $\mathrm{H}_{2} \mathrm{O}$. ${ }^{\text {a }}$ (continued)

3<smiles>CCC/C=C\COC(=N)C(Cl)(Cl)Cl</smiles>

$1 \mathrm{c}$<smiles>N=C(OC/C=C\CCc1ccccc1)C(Cl)(Cl)Cl</smiles>

$1 d$<smiles>CCC(/C=C/COC(=N)C(Cl)(Cl)Cl)CC</smiles>

$1 e$<smiles>N=C(OC/C=C/c1ccccc1)C(Cl)(Cl)Cl</smiles>

$1 f$

7<smiles>CC(C)/C=C\COC(=N)C(Cl)(Cl)Cl</smiles>

$1 \mathrm{~g}$

8<smiles>CS(=O)(=O)OC[18O]C/C=C\COC(=N)C(Cl)(Cl)Cl</smiles>

$1 \mathrm{~h}$

9<smiles>C=C([OH+])/C=C\COC(=N)C(Cl)(Cl)Cl</smiles>

10<smiles>CC(=O)CC/C=C\COC(C)=C(Cl)C(Cl)(Cl)Cl</smiles>

1j<smiles>C=CC(CCC)NC(=O)C(Cl)(Cl)Cl</smiles>

2

95

2c<smiles>C=CC(CCc1ccccc1)NC(=O)C(Cl)(Cl)Cl</smiles>

2

90

2d<smiles>C=CC(NC(=O)C(Cl)(Cl)Cl)C(CC)CC</smiles>

3

$67^{c}$

$2 \mathrm{e}$<smiles>C=CC(C)NC(=O)C(Cl)(Cl)Cl</smiles>

$2 f$<smiles>C=CC(C)(C)NC(=O)C(Cl)(Cl)Cl</smiles>

3

n.d. ${ }^{d}$

2g<smiles>C=CC(CO[Pb](C)(C)C)NC(=O)C(Cl)(Cl)Cl</smiles>

3

86

$2 \mathrm{~h}$<smiles>C=CC(C[OH+][I-])NC(=O)C(Cl)(Cl)Cl</smiles>

2

79

$2 i$<smiles>C=CC(CCC(C)=O)NC(C)=O</smiles>

2j

aUnless otherwise indicated, all reactions were carried out on a $0.5 \mathrm{mmol}$ scale with $5 \mathrm{~mol} \%$ of $\mathrm{AuCl}$ in $5 \mathrm{~mL} \mathrm{H}_{2} \mathrm{O}$ at $55^{\circ} \mathrm{C}$ for the indicated time;

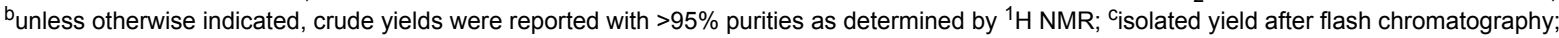
$\mathrm{d}_{\text {n.d. }}=$ not detected .

product (2e) in 67\% isolated yield (Table 2, entry 5). However, neither the substrates with phenyl (1f) nor dimethyl (1g) substituents at the $\mathrm{C} 1$ position gave the rearranged product (Table 2, entries 6 and 7), indicating that both electronic and steric effects at the $\mathrm{C} 1$ position play roles in the rearrangement. Although the substrate scope is currently limited to C1-alkyl substituted trichloroacetimidates, this method is still very convenient and attractive for the preparation of synthetically useful allylic amines. For example, substrates containing either TBDMS- or THP-protected hydroxy groups (1h and $\mathbf{1 i})$ efficiently underwent the desired rearrangement to afford the corresponding products, which are precursors for the synthesis of a variety of $\beta$-substituted $\beta$-amino alcohols (Table 2 , entries 8 and 9 ). Compound $\mathbf{2} \mathbf{j}$ was also obtained in $71 \%$ yield under the reaction conditions from the corresponding trichloroacetimidate $\mathbf{1 j}$ (Table 2, entry 10). Trichloroacetamide $\mathbf{2} \mathbf{j}$ could be 
transformed to vigabatrin, a GABA aminotransaminase inhibitor [36], in one single step [37].

One of the most remarkable features of this gold(I)-catalyzed Overman rearrangement is that it is performed in water under very mild reaction conditions. Moreover, this method is extremely clean. After completion of the reaction, simple extraction gave the desired product in high purity, and no further purification step was required. To illustrate the potential utility of this method for industrial applications, a gram-scale synthesis of 2 a was performed with $2 \mathrm{~mol} \%$ of $\mathrm{AuCl}$ in $\mathrm{H}_{2} \mathrm{O}$ (Scheme 1). After reacting at $55{ }^{\circ} \mathrm{C}$ for $4 \mathrm{~h}$, the desired product was obtained in $92 \%$ yield.

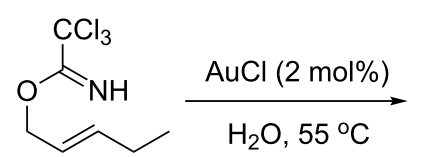

$1 \mathrm{a}$

$2.29 \mathrm{~g}$

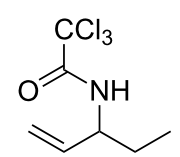

$2 a$

$2.11 \mathrm{~g}$ $92 \%$ yield
Scheme 1: Gram-scale synthesis of $2 a$.

\section{Conclusion}

In summary, we have developed an efficient gold(I)-catalyzed Overman rearrangement for the synthesis of a series of C3-alkyl substituted allylic trichloroacetamides. This transformation was performed in water under very mild reaction conditions and could be carried out on the gram-scale with low catalyst loading and simple work-up procedure, making it potentially applicable to the industrial community for large-scale synthesis. Further exploration of the substrate scope and the development of an asymmetric version of this transformation are currently underway in our group.

\section{Experimental}

Typical procedure: Synthesis of 2,2,2-trichloro-N(pent-1-en-3-yl)acetamide (2a)

$\mathrm{AuCl}(5.8 \mathrm{mg}, 0.025 \mathrm{mmol})$ was added to a solution of $(E)$ pent-2-enyl 2,2,2-trichloroacetimidate (1a) (115 mg, $0.5 \mathrm{mmol})$ in $\mathrm{H}_{2} \mathrm{O}(5 \mathrm{~mL})$ with vigorously stirring in a $25 \mathrm{~mL}$ reaction tube. The reaction mixture was heated at $55{ }^{\circ} \mathrm{C}$ for $2 \mathrm{~h}$, then cooled to room temperature, diluted with $\mathrm{H}_{2} \mathrm{O}$ and extracted with $\mathrm{CH}_{2} \mathrm{Cl}_{2}$ three times. The combined organic layers were dried over $\mathrm{MgSO}_{4}$, filtered through a short pad of celite and concentrated in vacuo to provide $107 \mathrm{mg}$ of 2,2,2-trichloro- $\mathrm{N}$ (pent-1-en-3-yl)acetamide (2a) ( $>95 \%$ purity as determined by ${ }^{1} \mathrm{H}$ NMR). Products $\mathbf{2 a}-\mathbf{2 d}, \mathbf{2} \mathbf{h}$ and $\mathbf{2 j}$ are known compounds and their data were identical to those reported in the literature.

\section{Supporting Information}

\section{Supporting Information File 1}

${ }^{1} \mathrm{H}$ NMR data and NMR spectra of products $\mathbf{2 a}-\mathbf{2 d}, \mathbf{2 g}-\mathbf{2 i}$.

[http://www.beilstein-journals.org/bjoc/content/

supplementary/1860-5397-7-88-S1.pdf]

\section{Acknowledgements}

This work was supported by The University of Hong Kong and Hong Kong Research Grants Council (HKU 706109P).

\section{References}

1. Overman, L. E. J. Am. Chem. Soc. 1974, 96, 597-599. doi:10.1021/ja00809a054

2. Overman, L. E. J. Am. Chem. Soc. 1976, 98, 2901-2910. doi:10.1021/ja00426a038

3. Overman, L. E. Acc. Chem. Res. 1980, 13, 218-224. doi:10.1021/ar50151a005

4. Overman, L. E. Angew. Chem., Int. Ed. Engl. 1984, 23, 579-586. doi:10.1002/anie.198405791

5. Metz, P.; Mues, C.; Schoop, A. Tetrahedron 1992, 48, 1071-1080. doi:10.1016/S0040-4020(01)88203-X

6. Johannsen, M.; Jørgensen, K. A. Chem. Rev. 1998, 98, 1689-1708. doi: $10.1021 / \mathrm{cr} 9703430$

7. Overman, L. E.; Carpenter, N. E. In Organic Reactions; Overman, L. E., Ed.; Wiley: Hoboken, NJ, 2005; Vol. 66, pp 653-760.

8. Nomura, H.; Richards, C. J. Chem.-Asian J. 2010, 5, 1726-1740. doi:10.1002/asia.201000131

9. Hollis, T. K.; Overman, L. E. J. Organomet. Chem. 1999, 576, 290-299. doi:10.1016/S0022-328X(98)01065-1

10. Anderson, C. E.; Overman, L. E. J. Am. Chem. Soc. 2003, 125, 12412-12413. doi:10.1021/ja037086r

11. Kirsch, S. F.; Overman, L. E.; Watson, M. P. J. Org. Chem. 2004, 69, 8101-8104. doi:10.1021/jo0487092

12. Watson, M. P.; Overman, L. E.; Bergman, R. G. J. Am. Chem. Soc. 2007, 129, 5031-5044. doi:10.1021/ja0676962

13. Peters, R.; Xin, Z.-q.; Maier, F. Chem.-Asian J. 2010, 5, 1770-1774. doi:10.1002/asia.201000386

14. Lutz, R. P. Chem. Rev. 1984, 84, 205-247. doi:10.1021/cr00061a001

15. Majumdar, K. C.; Alam, S.; Chattopadhyay, B. Tetrahedron 2008, 64, 597-643. doi:10.1016/j.tet.2007.10.079

16. Marion, N.; Nolan, S. P. Angew. Chem., Int. Ed. 2007, 46, 2750-2752. doi:10.1002/anie.200604773

17. Zhang, L. J. Am. Chem. Soc. 2005, 127, 16804-16805. doi:10.1021/ja056419c

18. Marion, N.; Díez-González, S.; de Frémont, P.; Noble, A. R.; Nolan, S. P. Angew. Chem., Int. Ed. 2006, 45, 3647-3650. doi:10.1002/anie.200600571

19. Buzas, A.; Istrate, F.; Gagosz, F. Org. Lett. 2006, 8, 1957-1959. doi:10.1021/ol0606839

20. Zhang, L.; Wang, S. J. Am. Chem. Soc. 2006, 128, 1442-1443. doi:10.1021/ja057327q

21. Wang, S.; Zhang, L. J. Am. Chem. Soc. 2006, 128, 8414-8415. doi:10.1021/ja062777j

22. Buzas, A. K.; Istrate, F. M.; Gagosz, F. Org. Lett. 2007, 9, 985-988. doi:10.1021/ol063031t 
23. Marion, N.; Gealageas, R.; Nolan, S. P. Org. Lett. 2007, 9, 2653-2656. doi:10.1021/ol070843w

24. Gourlaouen, C.; Marion, N.; Nolan, S. P.; Maseras, F. Org. Lett. 2009, 11, 81-84. doi:10.1021/ol802430m

25. Jaunzeme, I.; Jirgensons, A. Synlett 2005, 2984-2986. doi:10.1055/s-2005-918952

26. Jamieson, A. G.; Sutherland, A. Org. Biomol. Chem. 2006, 4, 2932-2937. doi:10.1039/b607014k

27. Swift, M. D.; Sutherland, A. Tetrahedron Lett. 2007, 48, 3771-3773. doi:10.1016/j.tetlet.2007.03.161

28. Jaunzeme, I.; Jirgensons, A. Tetrahedron 2008, 64, 5794-5799. doi:10.1016/j.tet.2008.03.099

29. Xing, D.; Yang, D. Org. Lett. 2010, 12, 1068-1071. doi:10.1021/ol100056f

30. Hutchings, G. J. Catal. Today 2007, 122, 196-200. doi:10.1016/j.cattod.2007.01.018

31. Wei, C.; Li, C.-J. J. Am. Chem. Soc. 2003, 125, 9584-9585. doi:10.1021/ja0359299

32. Huang, B.; Yao, X.; Li, C.-J. Adv. Synth. Catal. 2006, 348, 1528-1532. doi:10.1002/adsc.200606118

33. Lo, V. K.-Y.; Liu, Y.; Wong, M.-K.; Che, C.-M. Org. Lett. 2006, 8, 1529-1532. doi:10.1021/ol0528641

34. Xing, D.; Guan, B.; Cai, G.; Fang, Z.; Yang, L.; Shi, Z. Org. Lett. 2006, 8, 693-696. doi:10.1021/ol052830t

35. Nishikawa, T.; Asai, M.; Ohyabu, N.; Isobe, M. J. Org. Chem. 1998, 63, 188-192. doi:10.1021/jo9713924

36. Rogawski, M. A.; Löscher, W. Nat. Rev. Neurosci. 2004, 5, 553-564. doi:10.1038/nrn1430

37. Casara, P. Tetrahedron Lett. 1994, 35, 3049-3050. doi:10.1016/S0040-4039(00)76824-9

\section{License and Terms}

This is an Open Access article under the terms of the Creative Commons Attribution License (http://creativecommons.org/licenses/by/2.0), which permits unrestricted use, distribution, and reproduction in any medium, provided the original work is properly cited.

The license is subject to the Beilstein Journal of Organic Chemistry terms and conditions:

(http://www.beilstein-journals.org/bjoc)

The definitive version of this article is the electronic one which can be found at: doi:10.3762/bjoc. 7.88 